\title{
UHT Treatment on the Stability of Faba Bean Protein Emulsion ${ }^{\dagger}$
}

\author{
Malik Adil Nawaz ${ }^{1, *}$, Tanoj Kumar Singh ${ }^{1}$, Hema Jegasothy ${ }^{1}$ and Roman Buckow ${ }^{2}$ \\ 1 Commonwealth Scientific and Industrial Research Organisation (CSIRO), Agriculture and Food, \\ 671 Sneydes Road, Private Bag 16, Werribee, VIC 3030, Australia; Tanoj.singh@csiro.au (T.K.S.); \\ hema.jegasothy@csiro.au (H.J.) \\ 2 The University of Sydney, Centre for Advanced Food Enginomics, School of Chemical and Biomolecular \\ Engineering, Camperdown, NSW 2006, Australia; roman.buckow@sydney.edu.au \\ * Correspondence: malik.nawaz@csiro.au \\ + Presented at the 1st International Electronic Conference on Food Science and Functional Foods, \\ 10-25 November 2020; Available online: https://foods_2020.sciforum.net/.
}

\begin{abstract}
Faba beans are one of the most consumed legumes and an emerging source of edible legume-based protein. Efficacy of faba bean protein concentrate (available protein $\sim 63 \%$ ) during ultraheat treatment (UHT) processing of homogenised oil-in-water $(\mathrm{O} / \mathrm{W})$ emulsion was assessed in the present study by using four different concentrations viz., FPC5 5\%, FPC6 6\%, FPC7 7\%, and FPC $8 \sim 8 \%$. Additionally, the physicochemical properties of emulsion at various processing stages viz., coarse, homogenised, and UHT were also measured. Overall, this study showed the potential use of faba bean protein as a replica of soy protein in UHT processed legume-based beverages.
\end{abstract}

Keywords: legume proteins; emulsification; colloidal stability

Citation: Nawaz, M.A.; Singh, T.K.; Jegasothy, H.; Buckow, R. UHT Treatment on the Stability of Faba Bean Protein Emulsion. Proceedings 2021, 70, 29. https:// doi.org/10.3390/foods_2020-07742

Published: 10 November 2020

Publisher's Note: MDPI stays neutral with regard to jurisdictional claims in published maps and institutional affiliations.

Copyright: (c) 2020 by the authors. Licensee MDPI, Basel, Switzerland. This article is an open access article distributed under the terms and conditions of the Creative Commons Attribution (CC BY) license (http://creativecommons. org/licenses/by/4.0/).

\section{Introduction}

The use of plant proteins for human consumption foods begins since ancient times and appears especially in many traditional home dishes and cuisines in the Asian and Indian diets (such as soy beverages, tofu, tempeh, dosas) [1]. Industrialised food production has allowed mass production of plant proteins and new product innovation has transformed many of the traditional plant proteins products. A wide range of plant-proteinsbased foods and beverages, such as plant-based meat and milk analogues are commercially available [2,3]. In these food applications, the use of plant proteins extends beyond the nutritional values and provides functional purposes such as solubility, emulsification, gelation, and water and fat binding capacities [4]. These functionalities are critical to the successful application of plant proteins and the ultimate stability, quality, and acceptability of the finished products [5].

Plant-based beverage is normally an oil-in-water $(\mathrm{O} / \mathrm{W})$ emulsion, where water is the aqueous phase and oil is the dispersed phase. The two phases are generally immiscible and are thermodynamically unstable, where they tend to separate overtime via creaming, flocculation, coalescence, and/or aggregation [3]. One of the critical functionalities of plant proteins is their ability to adsorb at the oil-water interface and form stabilising protein films around the oil droplets. Plant proteins that are readily adsorbed at the interface, be able to unfold their structures and form a cohesive film around the oil droplets should generally be considered as effective emulsifier [6]. Many studies have evaluated the emulsifying properties of plant proteins such as soy [7], chickpea [8], peas [9], and beans [10], and have demonstrated the potential of plant proteins to serve as alternative proteins for stabilising $\mathrm{O} / \mathrm{W}$ emulsions. In terms of plant-protein-based beverages, common processing technologies such as high shear mixing, homogenisation, and ultra-heat treatment 
(UHT) can create pressure and thermal effects that can lead to changes in the stability of the protein emulsions [11].

Among the plant proteins, faba bean protein remains industrially underexploited and represents an emerging alternative source of plant protein. Faba bean, also known as fava bean or broad bean, is a legume rich in protein ( $250 \mathrm{~g}$ protein $/ \mathrm{kg}$ seed). The major storage proteins consist of two globulin proteins, 11S (legumin) and 7S (vicilin) [12]. Both globulin proteins exhibit different physiochemical and functional properties [13]. Several studies have reported the emulsifying potential of faba beans in various emulsion systems. Felix, et al. [14] evaluated the emulsifying properties of faba bean protein isolates ( $\sim 89 \%$ purity) in an O/W emulsion system consisting of sunflower oil dispersed in the aqueous phase. The greatest stability and the smallest droplet sizes were obtained for the emulsion system created at $\mathrm{pH} 8.0$ by high-shear mixing $(18,000 \mathrm{rpm})$ and two-stages homogenisation ( 800 and 80 bar). Raikos et al. [15] reported that the emulsifying ability and stability of faba bean flour (composed of $300 \mathrm{~g} \mathrm{~kg}^{-1}$ protein) were most superior when the emulsion was blended and homogenised $(12,000 \mathrm{rpm})$ with flaxseed oil at $\mathrm{pH} 10$. Liu et al. [16] studied the emulsifying properties of faba bean protein isolates by creating an emulsion system consisting of rapeseed oil dispersed in aqueous dispersion of hydrolysed faba bean protein isolates. The polypeptides produced (at $4 \%$ degree of hydrolysis by Alcalase) had suitable molecular mass, increased surface net charge and hydrophobicity, favouring emulsifying activity as evidenced by the homogenous droplet sizes and the high surface coverage of proteins at the interfacial layer. Karaca et al. [17] prepared a series of emulsions by blending flaxseed oil with respective aqueous solutions of faba bean, chickpea, lentil, pea, and soy protein isolates prepared with isoelectric precipitation and salt extraction. While all protein isolates prepared by isoelectric precipitation had superior emulsifying properties, the study also found similar emulsifying properties of faba bean protein isolates compared to soy and lentil protein isolates. Tsoukala et al. [18] reported superior stability, droplet size distribution, and protein surface load of emulsions consisted of corn oil blended with native faba bean meals, although modified faba bean meals (through induced autolysis) led to less stable emulsion systems over time. The authors deduced that the modified legume proteins with reduced solubility were not efficiently dissolved and not able to create a rigid film around the oil droplets for long term emulsion stability, though they have a less rigid structure adsorbed at a faster rate.

In this study, O/W emulsions were prepared by blending sunflower oil, sunflower lecithin, and faba bean protein concentrates at a controlled $\mathrm{pH}$ condition. The emulsions created by high shear mixing, homogenisation, and ultra-heat thermal processing were evaluated for their particle size, $\zeta$-potential, (protein and lipid) droplet size, surface hydrophobicity, flocculation, coalescence, and creaming index.

\section{Materials and Methods}

\section{Materials}

Faba bean protein concentrate (VITESSENCETM Pulse CT 3602 Protein) with $63 \%$ purity was obtained from Link Trading Queensland Pty Ltd., Richlands, QLD, Australia. The composition and caloric value of the faba protein concentrate (per $100 \mathrm{~g}$ ) are carbohydrate $(27 \mathrm{~g})$, total fat $(3 \mathrm{~g})$, protein content $(63 \mathrm{~g})$, moisture content $(3 \mathrm{~g})$, total ash $(4 \mathrm{~g})$, and calories $(410 \mathrm{KCal})$. Sunflower oil and soy lecithin (food grade) were purchased from a local grocery store. Faba bean protein isolate (available protein $\sim>85 \%$ ) and soy protein isolate (available protein $\sim 83 \%$ ) were produced in CSIRO pilot plant (Werribee, VIC, Australia). All chemicals including potassium phosphate (food grade), sodium dodecyl sulfate (SDS) 8-anilino-1-naphthalenesulfonic acid (ANS), methanol, and Nile red dye were purchased from Sigma-Aldrich, Castle Hill, NSW, Australia. Experimental design is presented in Figure 1. 


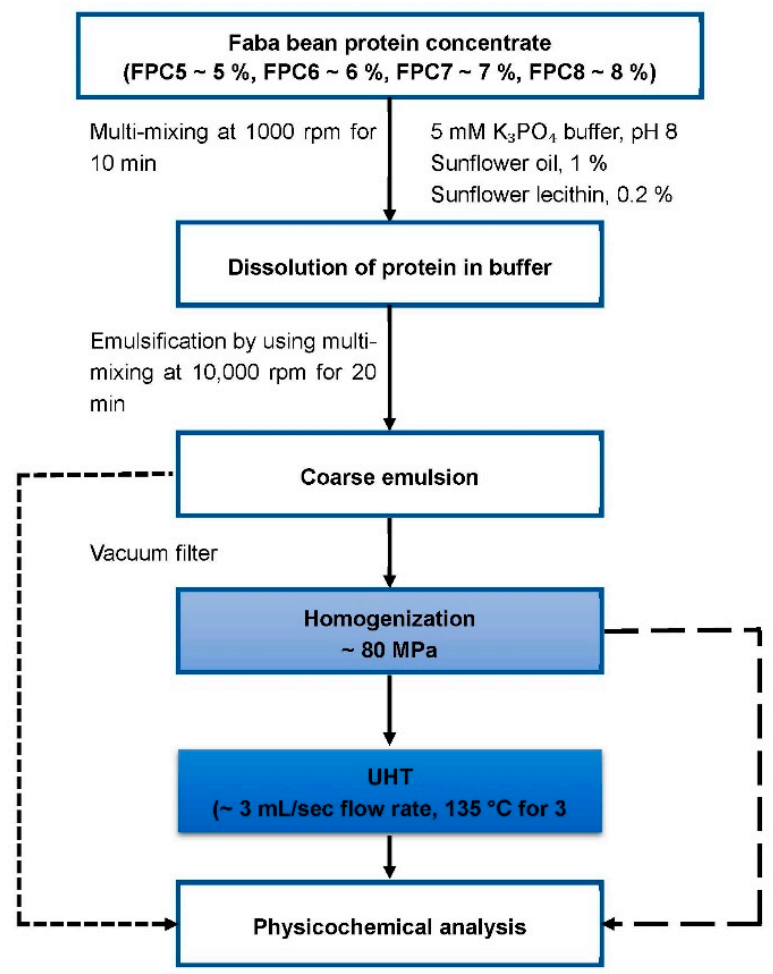

Figure 1. Experimental design.

\section{Preparation of Emulsion}

\subsection{Mixing}

Four different concentrations of faba bean concentrates (FPC5 5\%, FPC6 6\%, FPC7 $\sim 7 \%$, and FPC $8 \sim 8 \%$ ) were used in this study. Oil in water emulsion (approximately 3000 g) was prepared in $5 \mathrm{mM}$ phosphate buffer, $\mathrm{pH} 8.0$ by adding appropriate amount of the protein concentrate, sunflower oil $(1 \%)$, sunflower lecithin $(0.2 \%)$, and mixing with a multi-mixer at $1000 \mathrm{rpm}$ for $10 \mathrm{~min}$. The $\mathrm{pH}$ was then re-adjusted to 8.0 with $\mathrm{NaOH}$ prior to preparing the coarse emulsions (cFPC5, cFPC6, cFPC7, and cFPC8) by homogenising the lipidic and aqueous phases using multi-mixer at 10,000 rpm for $20 \mathrm{~min}$ and vacuum filtering to eliminate large undissolved material.

\subsection{Homogenisation of the Emulsion}

The coarse protein emulsions obtained by mixing with multi-mixer were further subjected to homogenisation treatment (hFPC5, hFPC6, hFPC7, and hFPC8). Each coarse emulsion was homogenised by single pass in an EmulsiFlex-C5 (Avestin, Ottawa, ON, Canada) operating at $\sim 80 \mathrm{MPa}$.

\subsection{Ultra-High Temperature Processing of the Emulsion}

The homogenised samples were subjected to UHT processing using a bench-top UHT plant (pre-heated to $105^{\circ} \mathrm{C}$ for $3 \mathrm{~s}$ and high heat-treated to $135^{\circ} \mathrm{C}$ for $3 \mathrm{~s}$ ). The UHT plant was operated at a flow rate of $3 \mathrm{~mL} / \mathrm{s}$. The UHT treated emulsions viz., uhtFPC5, uhtFPC6, uhtFPC7, and uhtFPC8.

\section{Physicochemical Properties of the Emulsion}

\subsection{Particle size Distribution}

The average particle size distribution of the protein emulsions was determined using a Malvern Mastersizer. The continuous phase of the experiment was Milli-Q water (Refractive Index: 1.33), whereas the dispersed phase was sunflower oil and plant protein. 
Particle size measurements was obtained around $12.5 \%$ laser obscuration and the proportion of droplet size distribution at $10 \%, 50 \%$, and $90 \%$ was $d(0.1), d(0.5)$, and $d(0.9)$, respectively. The uniformity, surface weighted mean $\mathrm{D}^{3,2}$, and volume weighted mean $\mathrm{D}^{4,3}$ was also obtained from the particle size distribution graphs [19]. The polydispersity index (PDI) was also calculated according to Equation (1).

$$
P D I=d(0.9)-d(0.1) / d(0.5)
$$

\subsection{Flocculation Index (FI) and Coalescence Index (CI)}

Flocculation refers to the process where undissolved particles clump together to form aggregates, making the emulsion unstable. Coalescence is the process by which two or more particles merge during contact to form a single large particle [20]. Flocculation index $(F I)$ and Coalescence index $(C I)$ of the protein emulsions were measured through $D^{4,3}$ values using the method of Felix, et al. [21]. Emulsions were dispersed at a ratio of $~ 1: 10$ either in deionised water $(D I)$ or $1 \%$ sodium dodecyl sulfate $(S D S)$ ) and $D^{4,3}$ values of freshly prepared and stored (after $24 \mathrm{~h}$ ) emulsions were obtained from the Mastersizer. For CI measurement, all emulsions were diluted only in 1\% SDS solution.

The FI and CI was calculated by Equations (2) and (3), respectively.

$$
\begin{gathered}
F I(\%)=\left[D^{4,3} \text { in water }-1\right] \times \frac{100}{D^{4,3} \text { in } S D S} \\
C I(\%)=\left[D^{4,3}(24 \mathrm{~h})-1\right] \times \frac{100}{D^{4,3}(0 \mathrm{~h})}
\end{gathered}
$$

where $D^{4,3}$ in water is sample diluted in water; $\mathrm{D}^{4,3}$ in SDS is sample diluted in sodium dodecyl sulfate (SDS); $D^{4,3}(24 \mathrm{~h})$ is sample stored for $24 \mathrm{~h}$ in the refrigerator $\left(\sim 4{ }^{\circ} \mathrm{C}\right)$; and $D^{4,3}(0 \mathrm{~h})$ is freshly prepared samples.

\subsection{Confocal Laser Scanning Microscopy}

The microscopic analysis of emulsion was done by labelling fat drop using Nile red followed by confocal laser scanning microscopy (CLSM) as described by Qamar, Bhandari and Prakash [11]. Sample of protein emulsion $(0.5 \mathrm{~mL})$ and $2 \mu \mathrm{L}$ of Nile red $(0.02 \% w / v$ in polyethylene glycol) was mixed properly using vortex mixer and kept in dark for $5 \mathrm{~min}$. A drop of the mixture was placed on a glass slide and used for measurement of lipid droplet size in the sample.

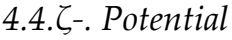

The $\zeta$-potential of the samples was measured using Marlven zetasizer as described by Li, et al. [22]. Freshly prepared, homogenised, and UHT-treated samples were pre-diluted 10-folds in a $5 \mathrm{mM}$ solution of phosphate buffer prepared with Milli-Q water (to avoid the coagulation effect due to high lipid concentration) and transferred to $\zeta$-potential cell. The $\zeta$-potential was measured at $25^{\circ} \mathrm{C}$ at a refractive index of 1.33 .

\subsection{Surface Hydrophobicity Index $\left(S_{o}\right)$}

The $\mathrm{S}_{\mathrm{o}}$ of selected samples of protein emulsion in aqueous solution was measured using 8-anilino-1-naphthalene sulfonic acid (ANS) as a fluorescent probe on a spectrofluorometer as described by Nwachukwu and Aluko [23]. Four different serial dilutions $(0.006 \%, 0.003 \%, 0.0012 \%$, and $0.0009 \%)$ of each stock solution of protein emulsion samples were prepared. Each dilution was further divided into two batches (with and without ANS solution). An amount of $20 \mu \mathrm{L}$ of ANS ( $8.0 \mathrm{mM}$ prepared in $5 \mathrm{mM}$ phosphate buffer) were added in $5 \mathrm{~mL}$ of the first batch of diluted protein samples while diluted protein samples without ANS was used as a blank. The ANS-protein conjugation was measured at $370 \mathrm{~nm}$ (excitation) and $490 \mathrm{~nm}$ (emission) wavelengths using a plate reader (Varioskan 
Flash, Thermo Scientific, Waltham, MA, USA). The $S_{\text {o }}$ was obtained through linear regression analysis of the plot between fluorescence intensity (FI) and protein concentrations (as the slope of fluorescence intensity-protein concentration).

\section{Creaming Index}

The creaming index of the freshly prepared emulsions was determined by centrifuging $5 \mathrm{~mL}$ of the emulsion in a plastic centrifuge tube (at $20^{\circ} \mathrm{C}$ and $4000 \mathrm{rpm}$ for $20 \mathrm{~min}$ ) using modified method of Liu et al. [24]. Each tube was then stored in the refrigerator $\left(\sim 4{ }^{\circ} \mathrm{C}\right)$ for 7 days. After 7 days of quiescent storage, the total height of emulsion $\left(H_{t}\right)$ and height of cream $\left(H_{c}\right)$ was measured. The percentage of creaming layer was calculated by using Equation (4).

$$
\text { Creaming index }=\left(\frac{H_{t}}{H_{c}}\right) \times 100
$$

\subsection{Sodium Dodecyl Sulphate Polyacrylamide Gel Electrophoresis (SDS-PAGE)}

Sodium dodecyl sulphate polyacrylamide gel electrophoresis (SDS-PAGE) was performed under reducing conditions. Mixtures of faba bean protein concentrate (FPC) having $\sim 63 \%$ protein, faba bean protein isolate (FPI) having $\sim 85 \%$ protein, and soy protein isolate (SPI) having $\sim 83 \%$ protein or reconstituted markers, were mixed with sample buffer and mercaptoethanol at a ratio 1:1:0.1, respectively, and heated in boiling water for 3 min followed by cooling in ice. Then, $4 \mu \mathrm{L}$ of treated samples/markers were loaded on gels and the electrophoresis was carried out at $60 \mathrm{Vh}$ for $40 \mathrm{~min}$. Protein bands were stained using Coomassie Brilliant Blue. The molecular weights (MWs) of unknown proteins were estimated via regression between the log of standard MWs and the relative mobility of the protein markers.

\subsection{Headspace Gas Chromatography-Mass Spectrometry (GC-MS)}

Aliquots $(\sim 5 \mathrm{~g})$ of selected samples of protein emulsions prepared fresh and UHT samples stored for a month at refrigerated temperature $\left(\sim 4^{\circ} \mathrm{C}\right)$ were weighed in amber $22 \mathrm{~mL}$ headspace vials and analysed for volatile organic compounds (VOCs). The analysis was performed using an Agilent gas chromatography mass spectrometry system (GCMS6890N model GC and 5975B model MSD; Agilent Technologies Australia Pty Ltd., Mulgrave, VIC, Australia) equipped with a CombiPAL robotic autosampler (CTC Analytics AG, Zwingen, Switzerland). Volatiles in the sample vial was extracted/concentrated from headspace on SPME fibre (carboxen/polydimethylsiloxane, CAR/PDMS; $85 \mu \mathrm{m}$ film thickness; $10 \mathrm{~mm}$ long; Supelco, Bellefonte, PA, USA) for $30 \mathrm{~min}$ at $50{ }^{\circ} \mathrm{C}$. SPME-sampled volatiles were thermally desorbed in the GC inlet and chromatographed on a VF-WAXms column (30 m $\times 0.32 \mathrm{~mm} \times 1.0 \mu \mathrm{m}$; Agilent Technologies) using a temperature gradient. Eluted compounds were detected by the MS. GCMS system was interfaced with the computer using MassHunter Workstation software (version 10.0; Agilent Technologies). Details on the set-up of GCMS, identification, and quantification of compounds were as detailed by [25].

\subsection{Statistical Analysis}

All experiments were performed in triplicate and the results are expressed in means \pm standard deviations. Experimental data was assessed by one-way analysis of variance (ANOVA) with Minitab 19 (Minitab $^{\circledR}$ for Windows Release 19, Minitab Inc., Chicago, IL, USA) to determine the significant differences. The data was then analysed using Tukeys pair-wise comparison, at $5 \%$ level of significance, to compare the results between different treatments. 


\section{Results and Discussion}

\section{UHT Processing of Faba Bean Protein Emulsions}

The homogenised emulsions of faba bean protein concentrate viz., hFPC5, hFPC6, hFPC7, and hFPC8, when subjected to UHT processing did not foul for the duration of the run $(\sim 1 \mathrm{~h})$. Fouling or depositing results in reduced flow rate, flow pressure, and outlet temperature, which was not observed in the UHT processing of faba bean protein emulsions. Flow rate, flow pressure, and outlet temperature were maintained at $3 \pm 1 \mathrm{~mL} / \mathrm{se}$, $200 \pm 20 \mathrm{kPa}$, and $135 \pm 1{ }^{\circ} \mathrm{C}$.

\section{Physicochemical Properties of the Emulsions}

\subsection{Particle Size Distribution}

The results of particle size distribution of coarse (cFPC5, cFPC6, cFPC7, and cFPC8), homogenised (hFPC5, hFPC6, hFPC7, and hFPC8), and UHT (uhtFPC5, uhtFPC6, uhtFPC7, and uhtFPC8) treated emulsions of faba bean protein concentrate are presented in Figure 2. Results showed that the UHT treatment resulted in increased particle size possibly due to thermal induced aggregation. The limitation of particle size distribution analysis is to distinguish between disperse particles, as the detection range of the equipment used is between 0.1 and $1000 \mu \mathrm{m}$. In this range, it is possible that the particle size analysis is including not only fat globules but also some protein aggregates and even protein-fat globule and globule aggregates [26].

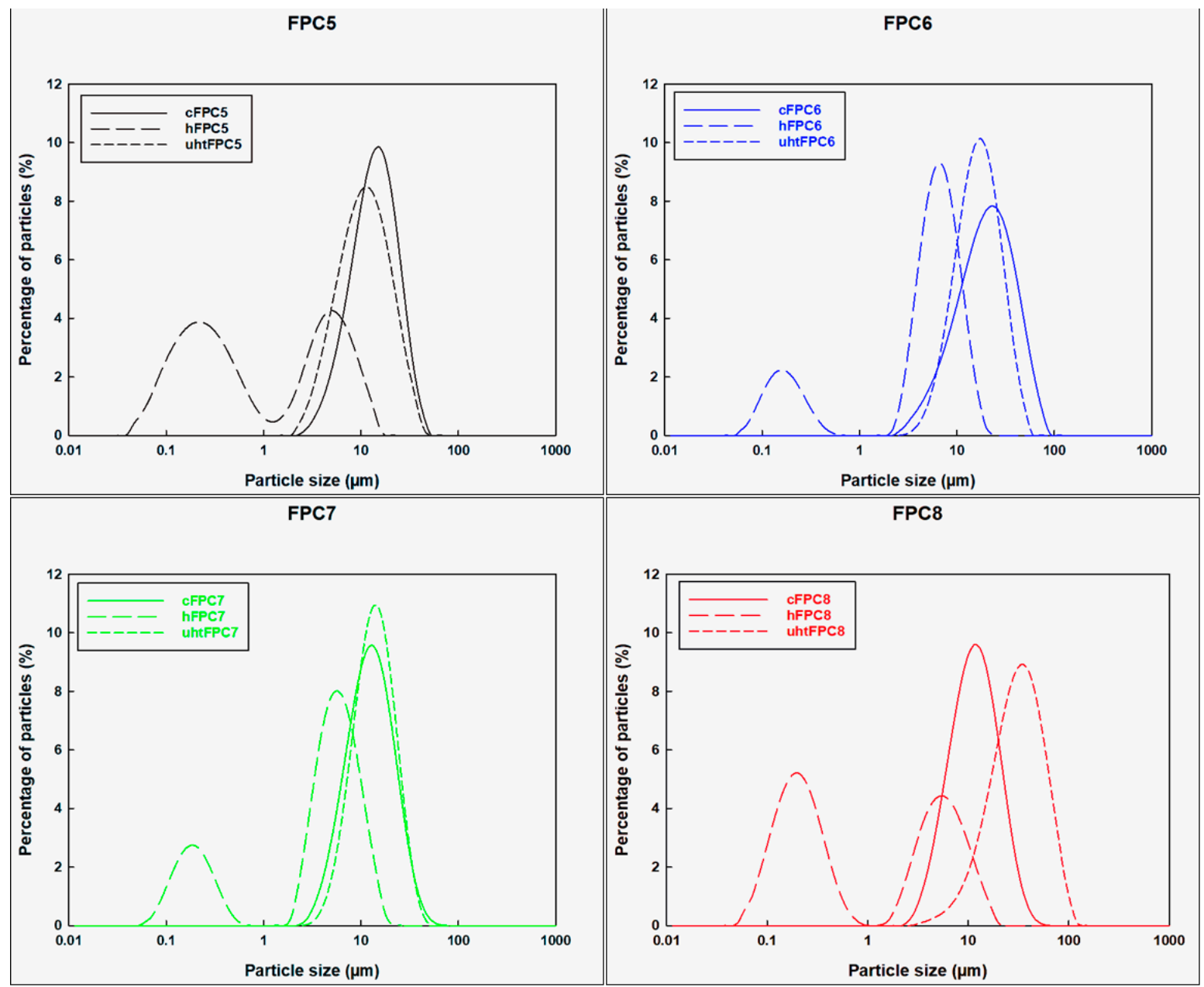

Figure 2. Particle size distribution curves of oil-in-water $(\mathrm{O} / \mathrm{W})$ emulsions with various concentrations of faba bean protein concentrate at various stages during ultra-heat treatment (UHT) processing. 


\subsection{Flocculation Index (FI) and Coalescence Index (CI)}

Flocculation and coalescence usually occur due to the attractive interactions or aggregation between the depleted surfactant ions resulting in a liquid-solid transition state. This will result in increased particle size and reduced emulsion stability [27]. Thus, the FI and $\mathrm{CI}$ are the indicative assessment of emulsion stability. The results of FI and $\mathrm{CI}$ for coarse (cFPC5, cFPC6, cFPC7, and cFPC8), homogenised (hFPC5, hFPC6, hFPC7, and hFPC8), and UHT (uhtFPC5, uhtFPC6, uhtFPC7, and uhtFPC8) treated emulsions of faba bean protein concentrate are presented in Table 1. Results showed that the FI and CI of emulsion varied with not only the protein concentration but also the processing stage. Increase in the protein concentration and thermal treatment during UHT processing caused an increased droplet flocculation [28]. The possible interactions between absorbed proteins within a droplet or between droplets might affect the viscosity of the emulsions. The formation of bridges between droplets as well as presence of droplets with large aggregates on the surface would also increase the viscosity of the emulsion [29]. Rheological experiments were not carried out on coarse, homogenised, and UHT emulsions with varying protein contents as particle size analysis already indicated the presence of aggregated oil droplets. Similar findings were observed in confocal laser scanning micrographs (CLSM) of coarse (cFPC5, cFPC6, cFPC7, and cFPC8), homogenised (hFPC5, hFPC6, hFPC7, and hFPC8), and UHT (uhtFPC5, uhtFPC6, uhtFPC7, and uhtFPC8) treated emulsions of faba bean protein concentrate are presented in Figure 3.

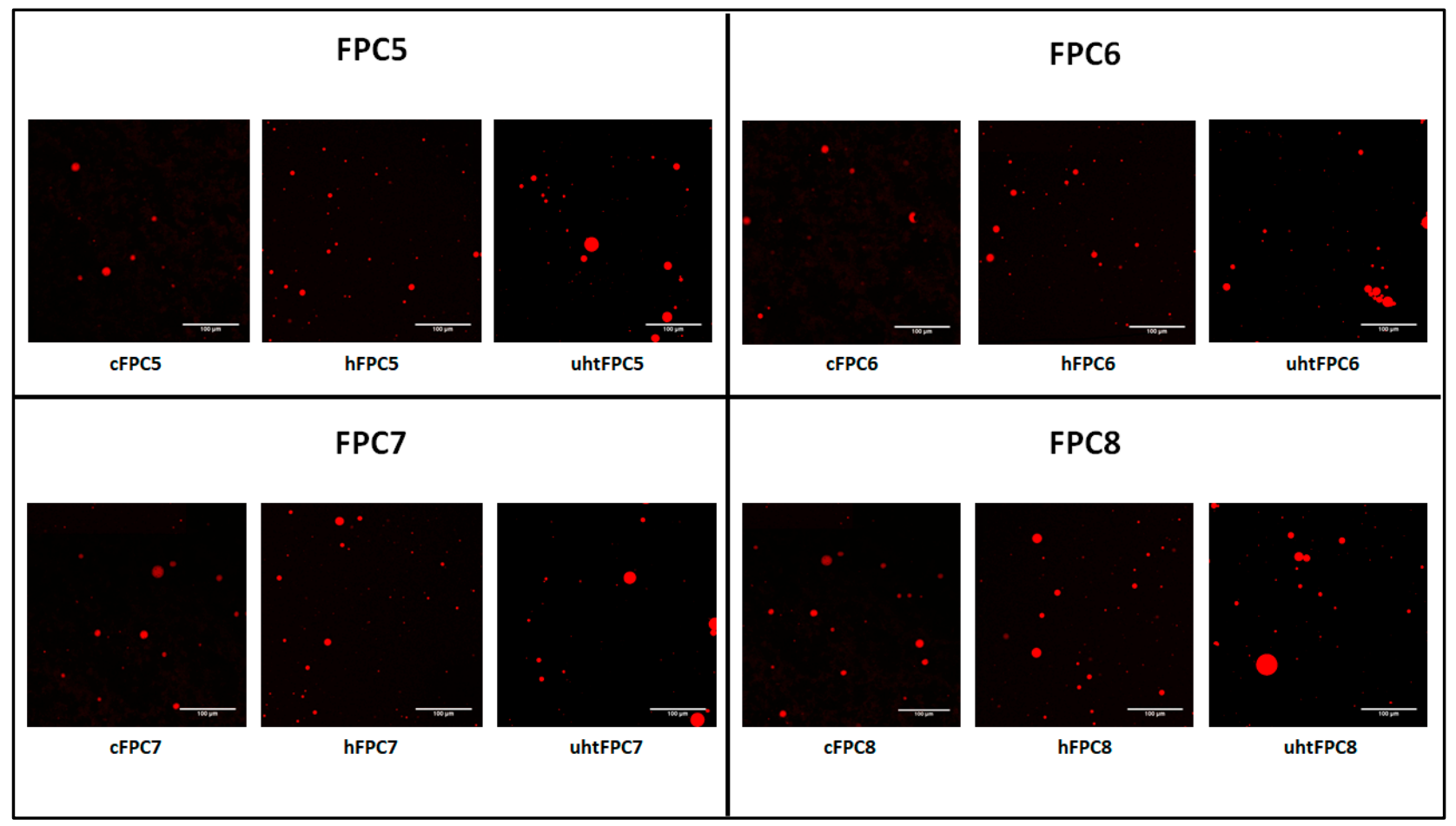

Figure 3. Confocal laser scanning micrographs of $\mathrm{O} / \mathrm{W}$ emulsions with various concentrations of faba bean protein concentrate at various stages during UHT processing. 
Table 1. Effect of faba bean protein concentration on the physicochemical properties viz., polydispersity index (PDI), flocculation index (FI), coalescence index (CI), $\zeta$-potential, and creaming index of $\mathrm{O} / \mathrm{W}$ emulsions at various stages during UHT processing *.

\begin{tabular}{ccccccc}
\hline Treatment & Emulsion Type & PDI $(\%)$ & FI & CI & $\zeta$-Potential (mV) & Creaming Index \\
\hline \multirow{3}{*}{ FPC5 } & coarse & $24.38 \pm 0.01^{\mathrm{c}}$ & $88.81 \pm 0.35^{\mathrm{d}}$ & $101.26 \pm 5.24^{\mathrm{cd}}$ & $-27.60 \pm 3.25^{\mathrm{d}}$ & $12.45 \pm 0.35^{\mathrm{b}}$ \\
\cline { 2 - 7 } & homogenised & $6.88 \pm 0.24^{\mathrm{e}}$ & $4.79 \pm 0.19^{\mathrm{e}}$ & $63.93 \pm 0.34^{\mathrm{ef}}$ & $-24.63 \pm 1.50^{\mathrm{cd}}$ & $7.00 \pm 0.28^{\mathrm{g}}$ \\
\cline { 2 - 7 } & UHT & $21.37 \pm 0.71^{\mathrm{cd}}$ & $105.06 \pm 3.66^{\mathrm{d}}$ & $142.34 \pm 9.92^{\mathrm{b}}$ & $-23.10 \pm 0.96^{\mathrm{bc}}$ & $9.25 \pm 021^{\mathrm{de}}$ \\
\hline \multirow{3}{*}{ FPC6 } & coarse & $41.52 \pm 5.45^{\mathrm{b}}$ & $160.82 \pm 17.80^{\mathrm{c}}$ & $101.57 \pm 2.24^{\mathrm{cd}}$ & $-23.10 \pm 2.10^{\mathrm{bc}}$ & $13.05 \pm 0.21^{\mathrm{b}}$ \\
\cline { 2 - 7 } & homogenised & $10.44 \pm 0.13^{\mathrm{de}}$ & $11.10 \pm 2.87^{\mathrm{e}}$ & $47.81 \pm 0.49^{\mathrm{f}}$ & $-21.20 \pm 0.80^{\mathrm{b}}$ & $7.20 \pm 0.42^{\mathrm{g}}$ \\
\cline { 2 - 7 } & UHT & $29.03 \pm 1.81^{\mathrm{c}}$ & $194.98 \pm 0.15^{\mathrm{ab}}$ & $175.32 \pm 4.81^{\mathrm{a}}$ & $-21.47 \pm 1.10^{\mathrm{bc}}$ & $10.25 \pm 0.50^{\mathrm{cd}}$ \\
\hline \multirow{3}{*}{ FPC7 } & coarse & $22.81 \pm 0.33^{\mathrm{c}}$ & $182.22 \pm 12.42^{\mathrm{bc}}$ & $110.95 \pm 5.30^{\mathrm{c}}$ & $-0.02 \pm 0.02^{\mathrm{a}}$ & $14.55 \pm 0.21^{\mathrm{a}}$ \\
\cline { 2 - 7 } & homogenised & $9.17 \pm 0.41^{\mathrm{e}}$ & $10.83 \pm 3.06^{\mathrm{e}}$ & $83.41 \pm 7.59^{\mathrm{de}}$ & $0.08 \pm 0.03^{\mathrm{a}}$ & $7.95 \pm 0.21^{\mathrm{fg}}$ \\
\cline { 2 - 7 } & UHT & $22.89 \pm 1.45^{\mathrm{c}}$ & $212.14 \pm 3.91^{\mathrm{ab}}$ & $191.81 \pm 11.82^{\mathrm{a}}$ & $-0.12 \pm 0.07^{\mathrm{a}}$ & $10.40 \pm 0.28^{\mathrm{c}}$ \\
\hline \multirow{3}{*}{ FPC8 } & coarse & $20.89 \pm 0.18^{\mathrm{cd}}$ & $199.74 \pm 18.27^{\mathrm{ab}}$ & $109.06 \pm 1.30^{\mathrm{c}}$ & $0.01 \pm 0.07^{\mathrm{a}}$ & $14.95 \pm 0.21^{\mathrm{a}}$ \\
\cline { 2 - 7 } & homogenised & $7.84 \pm 0.34^{\mathrm{e}}$ & $16.10 \pm 1.27^{\mathrm{e}}$ & $78.98 \pm 0.32^{\mathrm{de}}$ & $0.01 \pm 0.20^{\mathrm{a}}$ & $8.40 \pm 0.14^{\mathrm{ef}}$ \\
\cline { 2 - 7 } & UHT & $59.49 \pm 7.40^{\mathrm{a}}$ & $226.50 \pm 0.26^{\mathrm{a}}$ & $197.43 \pm 7.08^{\mathrm{a}}$ & $0.24 \pm 0.11^{\mathrm{a}}$ & $15.15 \pm 0.21^{\mathrm{a}}$ \\
\hline
\end{tabular}

* Values (mean \pm S.D.) are in triplicates $(n=3)$ and the values within a column followed by the same letter are not significantly different at $95 \%$ confidence level $(p<0.05)$.

\section{3. $\zeta-P o t e n t i a l$}

$\zeta$-potential is also an indication of emulsion stability. It is now quite well understood that the emulsions having low electronegativity are unstable and easily flocculate or coagulate during storage while the emulsions with more electronegativity are comparatively more stable due to more repulsive forces than attractive forces [30]. The $\zeta$-potential of coarse (cFPC5, cFPC6, cFPC7, and cFPC8), homogenised (hFPC5, hFPC6, hFPC7, and hFPC8), and UHT (uhtFPC5, uhtFPC6, uhtFPC7, and uhtFPC8) treated emulsions of faba bean protein concentrate are presented in Table 1 . Results showed that the $\zeta$-potential not only depends on the concentration of protein in emulsion but also on the processing stage. Low protein concentrations viz., FPC5 and FPC6 showed greater negative $\zeta$-potential and thereby high solubility through enhanced electrostatic repulsions than that of FPC7 and FPC8. In addition, processing stage especially UHT treatment resulted in less negative values compared to coarse and homogenised emulsions. This can be related to the formation of protein aggregate mainly at higher temperature and reduction of solubility. Similar findings were recorded in particle size analysis (Figure 2) and CLSM (Figure 3), where increased particle size distribution was detected.

\subsection{Surface Hydrophobicity $\left(S_{o}\right)$}

Surface hydrophobicity $\left(\mathrm{S}_{0}\right)$ is one of the most important surface-related properties of emulsion and it is directly related to the emulsifying properties especially emulsion stability [31]. The adsorbing ability of protein at the O/W interface in the emulsion can be determined by $S_{0}$ [32]. The $S_{0}$ of coarse ( (hFPC5, hFPC6, hFPC7, and hFPC8), and UHT (uhtFPC5, uhtFPC6, uhtFPC7, and uhtFPC8) treated emulsions of faba bean protein concentrate are presented in Figure 4. Results showed that the increase in protein concentration and thermal application during UHT resulted in increased $\mathrm{S}_{0}$. It is evident from the previous studies that the heat treatment has a direct influence on the emulsion [33]. Heat induces the reordering of hydrophobic side chains of protein network [34]. These reordered hydrophobic side chains behave like an elastic gel, resulting in increased $S_{0}$ [35]. 


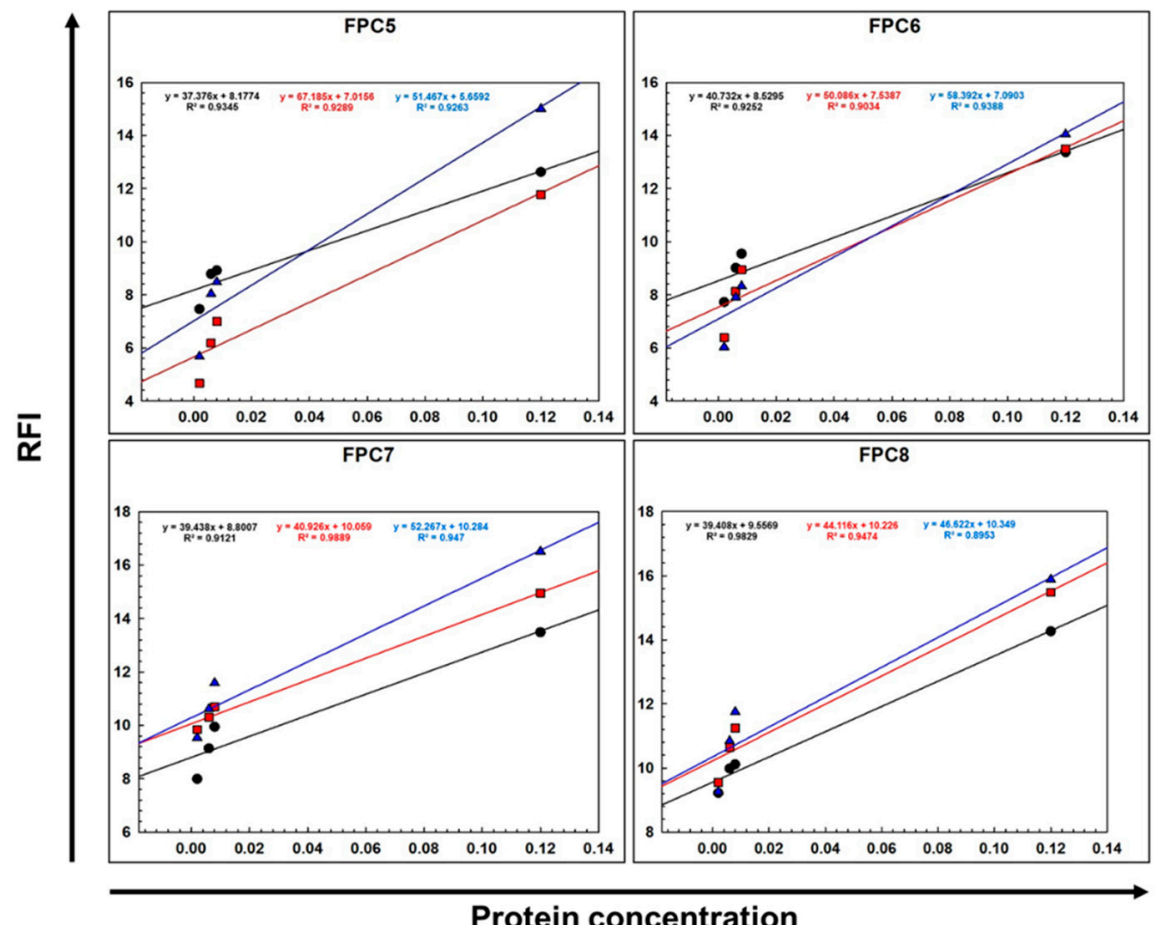

Figure 4. Effects of protein concentration and various stages of UHT processing viz., coarse homogenised $(\square)$, and UHT $(\mathbf{\Delta})$ on the surface hydrophobicity $\left(\mathrm{S}_{\mathrm{o}}\right)$.

\subsection{Creaming Index}

Creaming index or gravitational separation is also an indication of emulsion stability [36]. The creaming indexes of coarse (cFPC5, cFPC6, cFPC7, and cFPC8), homogenised (hFPC5, hFPC6, hFPC7, and hFPC8), and UHT (uhtFPC5, uhtFPC6, uhtFPC7, and uhtFPC8) treated emulsions of faba bean protein concentrate are presented in Table 1. Results showed that the creaming index not only depends on the concentration of protein in emulsion but also on the processing stage. Higher protein concentrations viz., FPC7 and FPC8 showed more creaming index compared to lesser protein emulsions viz., FPC5 and FPC6. Also, thermal application during UHT processing induced increased cream separation in all treatments.

\subsection{Sodium Dodecyl Sulphate Polyacrylamide Gel Electrophoresis (SDS-PAGE)}

The SDS-PAGE for faba bean protein concentrate (FPC) having $\sim 63 \%$ protein, faba bean protein isolate (FPI) having > 85\% protein, and soy protein isolate (SPI) having $\sim 83 \%$ protein is presented in Figure 5. Results showed similarities in the protein composition of both faba and soy (mainly 11S globulin-Glycinin and 7S globulin- $\beta$-conglycinin). The molecular weights for 7S proteins are between 45 and $97 \mathrm{kDa}$, and for $11 \mathrm{~S}$ are below $36 \mathrm{kDa}$ [37]. 


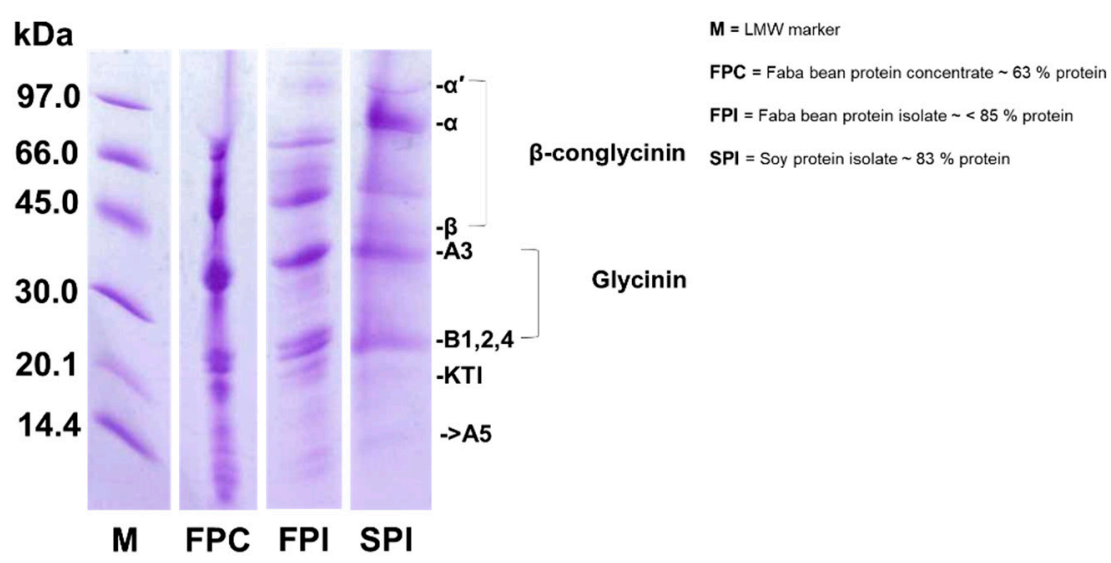

Figure 5. SDS-PAGE patterns of low molecular weight marker (M), faba bean protein concentrate (FPC), faba bean protein isolate (FPI), and soy protein isolate (SPI).

\subsection{Headspace Gas Chromatography-Mass Spectrometry (GC-MS)}

Volatile compounds profiling of products at each of the above three steps of manufacture of model faba protein-based beverage was performed by headspace GCMS analysis. In total 21 compounds were detected and quantified, representing different chemical classes such as alcohols, aldehydes, ketones, esters, furan, and acids. These volatiles have major consequences for the overall flavour chemistry of the model beverage product.

Origins of majority of these volatile organic compounds can be attributed to oxidative deterioration of lipids. Several lipid oxidation derived compounds are known potent odorants with extremely low human sensory detection thresholds, namely pentanal, hexanal, heptanal, nonanal, E-2-heptenal, and 2-pentyl furan. Odour notes mainly attributed to these compounds are green, grassy, leafy, cardboard, beany, rancid, etc. These compounds are primarily oil soluble and also known to be adsorbed on to the proteins. Concentration of volatiles in general increased at each of the steps involved in the manufacture of the model beverage (Figure 6).

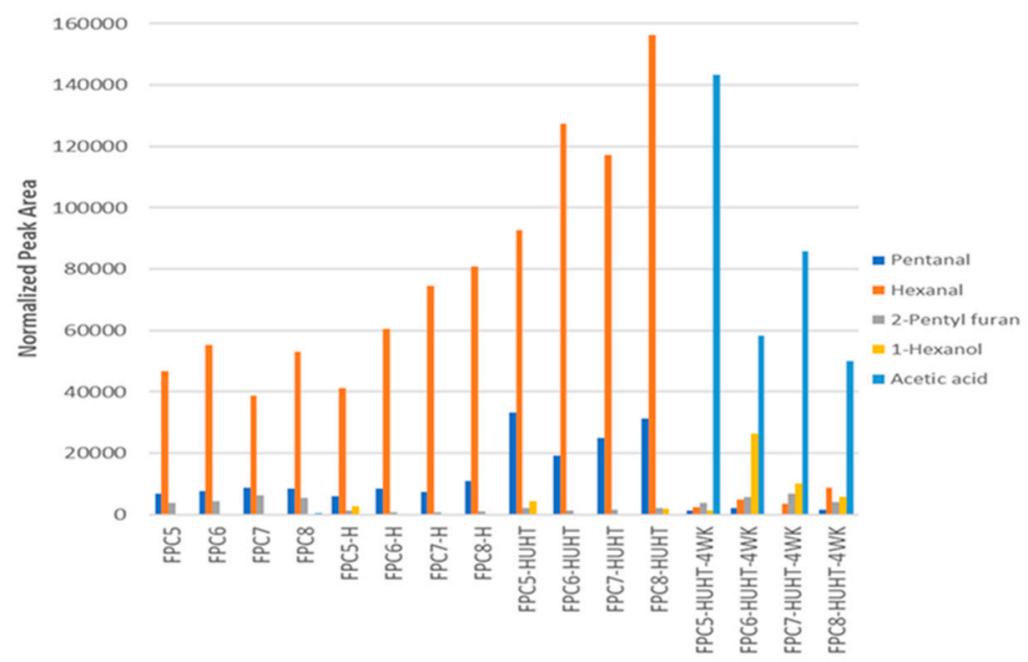

Figure 6. Changes in the concentration of key volatile organic compounds during manufacture of model faba protein-based beverage and storage. Three distinct steps were: 1 -preparation of coarse emulsion (samples FPC5-8; FPC, faba protein concentrate), 2-homogenisation of coarse emulsion (samples FPC7-8-H; H, homogenisation), and 3-thermal stabilisation model beverage by UHT treatment (samples FPC7-8-HUHT; UHT, ultra-high temperature). Thermally stabilised beverages were stored at $4{ }^{\circ} \mathrm{C}$ for 4 weeks. 
This increase in the levels of volatiles could be attributed to the thermal degradation of lipid oxidation derived intermediate compounds, namely hydroperoxides of various unsaturated fatty acids. Volatiles profiling of thermally stabilised samples of model beverages stored for 4 weeks at refrigerated temperature clearly showed formation of micro$\mathrm{bial} /$ fermentation activity with the production of elevated levels of acetic acid. In addition, it was also noted that levels of key lipid oxidation derived volatile aldehydes, e.g., pentanal, hexanal, etc., significantly reduced with concomitant increase in the levels of corresponding alcohols like 1-hexanol. This reduction in aldehyde could be attributed to reductive enzymes of microbial cells. Principal component analysis was performed on the quantitative volatile data in order to elucidate underlying trends/pattern (Figure 7). PCA bi plot captures $70 \%$ of underlying variation in the data and clearly highlighted key biochemical reaction mechanisms involved production and storage, namely, lipid oxidation and fermentation/microbial degradation during production/processing and storage, respectively.

In model plant protein beverage described above, these compounds find their way in from faba protein concentrate where these compounds were most likely produced via enzymatic oxidation of faba bean lipids occurring during the processing and production of protein ingredient from faba beans.

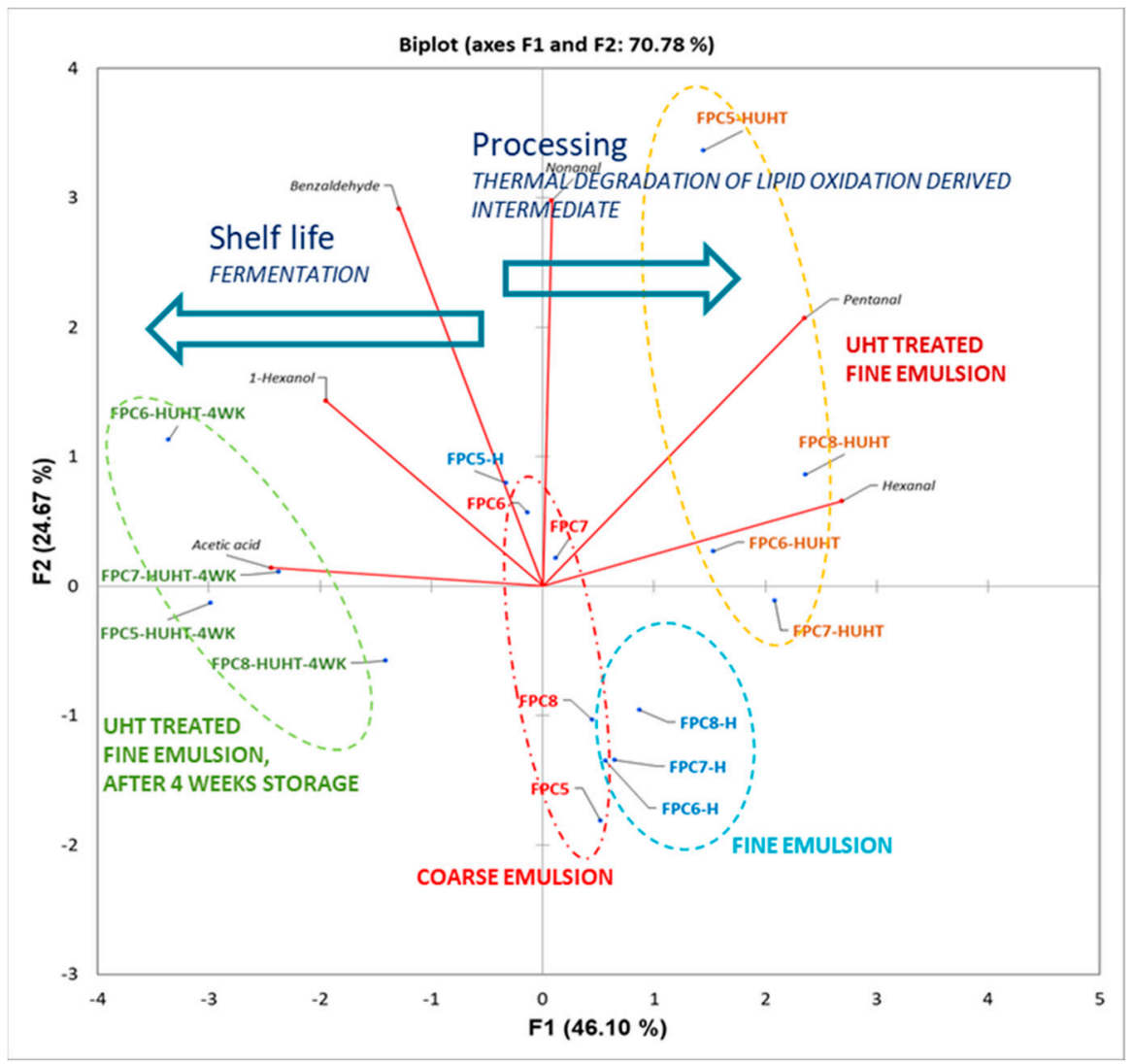

Figure 7. Principal component analysis of quantitative data from volatile analysis on model beverages during manufacture of model Faba protein-based beverage and storage.

\section{Conclusions}

Findings of the present studies showed that faba bean has a similar protein like soybean and can be used as a soy replica in plant-based milk alternatives. Faba bean protein emulsions with $8 \%$ protein showed induced gelation after UHT. Therefore, further research is planned to overcome this challenge. 
Acknowledgments: Authors would like to acknowledge the CSIRO Precision Health Future Science Platform for financial support.

\section{References}

1. Young, V.R.; Pellett, P.L. Plant proteins in relation to human protein and amino acid nutrition. Am. J. Clin. Nutr. 1994, 59, 1203S1212S, doi:10.1093/ajcn/59.5.1203S.

2. McClements, D.J.; Newman, E.; McClements, I.F. Plant-based Milks: A Review of the Science Underpinning Their Design, Fabrication, and Performance. Compr. Rev. Food Sci. Food Saf. 2019, 18, 2047-2067.

3. Nawaz, M.A.; Tan, M.; Øiseth, S.; Buckow, R. An Emerging Segment of Functional Legume-Based Beverages: A Review. Food Rev. Int. 2020, 1-39, doi:10.1080/87559129.2020.1762641.

4. Li-Chan, E.C.Y.; Lacroix, I.M.E. 1-Properties of proteins in food systems: An introduction. In Proteins in Food Processing, 2nd ed.; Yada, R.Y., Ed.; Woodhead Publishing: Sawston, UK, 2018; pp. 1-25, doi:10.1016/B978-0-08-100722-8.00002-4.

5. Queirós, R.P.; Saraiva, J.A.; da Silva, J.A.L. Tailoring structure and technological properties of plant proteins using high hydrostatic pressure. Crit. Rev. Food Sci. Nutr. 2018, 58, 1538-1556, doi:10.1080/10408398.2016.1271770.

6. Damodaran, S. Protein Stabilization of Emulsions and Foams. J. Food Sci. 2005, 70, R54-R66, doi:10.1111/j.13652621.2005.tb07150.x.

7. Fernandez-Avila, C.; Trujillo, A.J. Ultra-High Pressure Homogenization improves oxidative stability and interfacial properties of soy protein isolate-stabilized emulsions. Food Chem. 2016, 209, 104-113, doi:10.1016/j.foodchem.2016.04.019.

8. Wang, S.; Chelikani, V.; Serventi, L. Evaluation of chickpea as alternative to soy in plant-based beverages, fresh and fermented. LWT 2018, 97, 570-572, doi:10.1016/j.lwt.2018.07.067.

9. Chao, D.; Aluko, R.E. Modification of the structural, emulsifying, and foaming properties of an isolated pea protein by thermal pretreatment. Cyta-J. Food 2018, 16, 357-366, doi:10.1080/19476337.2017.1406536.

10. Qamar, S.; Bhandari, B.; Prakash, S. Effect of different homogenisation methods and UHT processing on the stability of pea protein emulsion. Food Res. Int. 2019, 116, 1374-1385, doi:10.1016/j.foodres.2018.10.028.

11. Multari, S.; Stewart, D.; Russell, W.R. Potential of Fava Bean as Future Protein Supply to Partially Replace Meat Intake in the Human Diet. Compr. Rev. Food Sci. Food Saf. 2015, 14, 511-522, doi:10.1111/1541-4337.12146.

12. Kimura, A.; Fukuda, T.; Zhang, M.; Motoyama, S.; Maruyama, N.; Utsumi, S. Comparison of Physicochemical Properties of $7 S$ and 11S Globulins from Pea, Fava Bean, Cowpea, and French Bean with Those of Soybean-French Bean 7S Globulin Exhibits Excellent Properties. J. Agric. Food Chem. 2008, 56, 10273-10279, doi:10.1021/jf801721b.

13. Felix, M.; Cermeño, M.; FitzGerald, R.J. Assessment of the microstructural characteristics and the in vitro bioactive properties of sunflower oil-based emulsions stabilized by fava bean (Vicia faba) protein. Food Hydrocoll. 2019, 97, 105220, doi:10.1016/j.foodhyd.2019.105220.

14. Raikos, V.; Neacsu, M.; Russell, W.; Duthie, G. Comparative study of the functional properties of lupin, green pea, fava bean, hemp, and buckwheat flours as affected by pH. Food Sci. Nutr. 2014, 2, 802-810, doi:10.1002/fsn3.143.

15. Liu, C.; Bhattarai, M.; Mikkonen, K.S.; Heinonen, M. Effects of Enzymatic Hydrolysis of Fava Bean Protein Isolate by Alcalase on the Physical and Oxidative Stability of Oil-in-Water Emulsions. J. Agric. Food Chem. 2019, 67, 6625-6632, doi:10.1021/acs.jafc.9b00914.

16. Karaca, A.C.; Low, N.; Nickerson, M. Emulsifying properties of chickpea, faba bean, lentil and pea proteins produced by isoelectric precipitation and salt extraction. Food Res. Int. 2011, 44, 2742-2750, doi:10.1016/j.foodres.2011.06.012.

17. Tsoukala, A.; Papalamprou, E.; Makri, E.; Doxastakis, G.; Braudo, E.E. Adsorption at the air-water interface and emulsification properties of grain legume protein derivatives from pea and broad bean. Colloids Surf. B: Biointerfaces 2006, 53, 203-208, doi:10.1016/j.colsurfb.2006.08.019.

18. Rahmati, N.F.; Koocheki, A.; Varidi, M.; Kadkhodaee, R. Thermodynamic compatibility and interactions between Speckled Sugar bean protein and xanthan gum for production of multilayer O/W emulsion. J. Food Sci. Technol. 2018, 55, 1143-1153, doi:10.1007/s13197-017-3030-9.

19. Oliete, B.; Potin, F.; Cases, E.; Saurel, R. Microfluidization as Homogenization Technique in Pea Globulin-Based Emulsions. Food Bioprocess Technol. 2019, 12, 877-882, doi:10.1007/s11947-019-02265-3.

20. Felix, M.; Cermeño, M.; Romero, A.; FitzGerald, R.J. Characterisation of the bioactive properties and microstructure of chickpea protein-based oil in water emulsions. Food Res. Int. 2019, 121, 577-585, doi:10.1016/j.foodres.2018.12.022.

21. Li, Q.; Wang, Z.; Dai, C.; Wang, Y.; Chen, W.; Ju, X.; Yuan, J.; He, R. Physical stability and microstructure of rapeseed protein isolate/gum Arabic stabilized emulsions at alkaline pH. Food Hydrocoll. 2019, 88, 50-57, doi:10.1016/j.foodhyd.2018.09.020.

22. Nwachukwu, I.D.; Aluko, R.E. Physicochemical and emulsification properties of flaxseed (Linum usitatissimum) albumin and globulin fractions. Food Chem. 2018, 255, 216-225, doi:10.1016/j.foodchem.2018.02.068. 
23. Liu, N.; Chen, Q.; Li, G.; Zhu, Z.; Yi, J.; Li, C.; Chen, X.; Wang, Y. Properties and Stability of Perilla Seed Protein-Stabilized Oilin-Water Emulsions: Influence of Protein Concentration, $\mathrm{pH}, \mathrm{NaCl}$ Concentration and Thermal Treatment. Molecules 2018, 23, 1533.

24. Torkamani, A.E.; Juliano, P.; Ajlouni, S.; Singh, T.K. Impact of ultrasound treatment on lipid oxidation of Cheddar cheese whey. Ultrason. Sonochemistry 2014, 21, 951-957, doi:10.1016/j.ultsonch.2013.11.021.

25. Ahmadian-Kouchaksaraei, Z.; Varidi, M.; Varidi, M.J.; Pourazarang, H. Influence of processing conditions on the physicochemical and sensory properties of sesame milk: A novel nutritional beverage. Lwt-Food Sci. Technol. 2014, 57, 299-305, doi:10.1016/j.lwt.2013.12.028.

26. Ralla, T.; Salminen, H.; Braun, K.; Edelmann, M.; Dawid, C.; Hofmann, T.; Weiss, J. Investigations into the Structure-Function Relationship of the Naturally-Derived Surfactant Glycyrrhizin: Emulsion Stability. Food Biophys. 2020, 15, 288-296, doi:10.1007/s11483-020-09624-0.

27. Dickinson, E. Flocculation of protein-stabilized oil-in-water emulsions. Colloids Surf. B Biointerfaces 2010, 81, 130-140, doi:10.1016/j.colsurfb.2010.06.033.

28. Keerati-u-rai, M.; Corredig, M. Heat-induced changes in oil-in-water emulsions stabilized with soy protein isolate. Food Hydrocoll. 2009, 23, 2141-2148, doi:10.1016/j.foodhyd.2009.05.010.

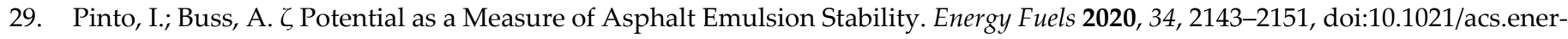
gyfuels.9b03565.

30. Lee, J.; Jo, S.H.; Lim, J. Effect of surface modification of $\mathrm{CaCO}_{3}$ nanoparticles by a silane coupling agent methyltrimethoxysilane on the stability of foam and emulsion. J. Ind. Eng. Chem. 2019, 74, 63-70, doi:10.1016/j.jiec.2019.02.002.

31. Mahmoudi, N.; Axelos, M.A.V.; Riaublanc, A. Interfacial properties of fractal and spherical whey protein aggregates. Soft Matter 2011, 7, 7643-7654.

32. Zhai, J.1.; Day, L.; Aguilar, M.-I.; Wooster, T.J. Protein folding at emulsion oil/water interfaces. Curr. Opin. Colloid Interface Sci. 2013, 18, 257-271, doi:10.1016/j.cocis.2013.03.002.

33. Cioci, F.; Lavecchia, R. Molecular thermodynamics of heat-induced protein unfolding in aqueous media. Aiche J. 1997, 43, 525534, doi:10.1002/aic.690430225.

34. Caplan, M.R.; Schwartzfarb, E.M.; Zhang, S.; Kamm, R.D.; Lauffenburger, D.A. Control of self-assembling oligopeptide matrix formation through systematic variation of amino acid sequence. Biomaterials 2002, 23, 219-227.

35. Hosseini, A.; Jafari, S.M.; Mirzaei, H.; Asghari, A.; Akhavan, S. Application of image processing to assess emulsion stability and emulsification properties of Arabic gum. Carbohydr. Polym. 2015, 126, 1-8, doi:10.1016/j.carbpol.2015.03.020.

36. Wu, W.; Zhang, C.; Kong, X.; Hua, Y. Oxidative modification of soy protein by peroxyl radicals. Food Chem. 2009, 116, 295-301, doi:10.1016/j.foodchem.2009.02.049.

37. Warsame, A.O.; Michael, N.; O'Sullivan, D.M.; Tosi, P. Identification and quantification of major faba bean seed proteins. J. Agric. Food Chem. 2020, 68, 8535-8544, doi:10.1021/acs.jafc.0c02927. 